\title{
Methods for the evaluation of antibiotic resistance in Lactobacillus isolated from fermented sausages
}

\author{
Hanna Lethycia Wolupeck ${ }^{1}$ Crisley Aparecida Morete $^{1}$ Osmar Roberto DallaSanta ${ }^{2}$ \\ Fernando Bittencourt Luciano ${ }^{1}$ Humberto Maciel França Madeira ${ }^{1}$ \\ Renata Ernlund Freitas de Macedo ${ }^{1^{*}}$
}

${ }^{1}$ Programa de Pós-graduação em Ciência Animal, Escola de Ciências da Vida, Pontifícia Universidade Católica do Paraná (PUCPR), 80215-901, Curitiba, PR, Brasil. E-mail: renata.macedo@pucpr.br. "Corresponding author.

${ }^{2}$ Departamento de Engenharia de Alimentos, Universidade Estadual do Centro-Oeste (UNICENTRO), Guarapuava, PR, Brasil.

\begin{abstract}
The present study aimed to assess the antibiotic resistance in 54 indigenous Lactobacillus plantarum isolated from artisanal fermented sausages. The confirmation of the strain species was performed by multiplex-PCR assay. Antibiotic resistance was assessed by disk diffusion (DD) and Minimum Inhibitory Concentration (MIC) methods. Of 54 L. plantarum, 44 strains were genotypically confirmed as L. plantarum and 3 as Lactobacillus pentosus. The highest resistance rates were to ampicillin and streptomycin. The highest susceptibility rates were shown to tetracycline, chloramphenicol and penicillin G. None of the strains showed multidrug resistance. Resistance rates by DD and MIC were not different $(P>0.05)$ for ampicillin, chloramphenicol, erythromycin and penicillin $G$. Future research should assess the genetic mechanisms underlying the phenotypic resistance in Lactobacillus strains to screen the potential probiotic strains for the development of functional meat products.

Key words: meat product, multiplex PCR, probiotic, susceptibility.
\end{abstract}

\section{Comparação de métodos para avaliação de resistência microbiana em Lactobacillus} isolados de embutidos fermentados

RESUMO: O presente estudo teve como objetivo avaliar a resistência a antibióticos, de 54 cepas nativas de Lactobacillus plantarum isoladas de salames artesanais. A confirmação genotípica da espécie foi realizada por ensaio de PCR multiplex. A resistência aos antibióticos foi avaliada pelos métodos de disco difusão e concentração inibitória mínima. Das 54 cepas, 44 foram confirmadas genotipicamente como L. plantarum e 3 como Lactobacillus pentosus. As maiores frequências de resistência foram para ampicilina e estreptomicina, e as maiores frequências de sensibilidade para tetraciclina, cloranfenicol e penicilina $G$. Nenhuma das cepas apresentou multirresistência. As frequências de resistência para ampicilina, cloranfenicol, eritromicina e penicilina $G$ foram semelhantes pelos métodos testados (P>0,05). Pesquisas futuras devem ser realizadas para avaliar os mecanismos genéticos envolvidos na resistência fenotípica das cepas de Lactobacillus, no intuito de selecionar as potenciais cepas probióticas para aplicação em produtos cárneos funcionais.

Palavras-chave: multiplex PCR, probióticos, produto cárneo, susceptibilidade.

\section{INTRODUCTION}

The most common species of lactic acid bacteria (LAB) used as starter cultures in fermented sausages are Lactobacillus plantarum, Lactobacillus pentosus, Lactobacillus sakei, Lactobacillus curvatus, Lactobacillus casei, Pediococcus pentosaceus and Pediococcus acidilactici (KLINGBERG et al., 2005). These microorganisms play an important role in the production of fermented sausages, by increasing the microbiological safety and improving the sensory characteristics. More recently, probiotic starter cultures are also been used to increase the functional value of fermented sausages.

Because meat products conditions are generally not favorable for the growth of most of the LAB already characterized as probiotic; the isolation, identification and assessment of probiotic potential in indigenous LAB from fermented meat products might be an interesting strategy for the development of probiotic cultures for the meat industry (KLINGBERG et al., 2005).

Currently, the GRAS (Generally Recognized as Safe) status of the probiotic bacteria also includes the antibiotic resistance, evaluated by the Qualified 
Prediction Security Program (QPSP), suggested by the European Food Safety Authority (EFSA, 2013). This is an important criterion for the selection of probiotics due to the possibility of the genetic transmission of the antimicrobial resistance among different bacteria.

Intrinsic resistance is the innate ability of a bacterial species or genus to resist to an antimicrobial agent through its inherent structural or functional characteristics. This resistance is known as vertical gene transfer, in which resistance genes are transferred directly to all the bacteria's progeny during DNA replication. Conversely, acquired resistance occurs through acquisition of exogenous DNA or mutation of wild genes (EFSA, 2008). Thus, genes can be horizontally transferred to other bacteria.

Therefore, acquired resistance has become a concern in the selection of probiotic bacteria because beneficial bacteria can transfer resistant genes to potentially pathogenic bacteria in the gut of the host. A report on global surveillance of antimicrobial resistance by the World Health Organization (WHO, 2014) evidences a link between antimicrobials drugs use in food-producing animals and emergence of resistance among common pathogens. This could lead to an ineffectiveness of antibiotic therapy used for both, treating or preventing infections.

The present study aimed to assess the antibiotic resistance, by two different methodologies, in indigenous L. plantarum strains isolated from artisanal fermented sausages, prospecting their future use as probiotics starters in meat products.

\section{MATERIALS AND METHODS}

\section{Molecular confirmation of L. plantarum species} Fifty four (54) indigenous Lactobacillus strains isolated from fermented sausages (DALLA SANTA et al., 2012) and phenotypically identified by API $50 \mathrm{CHL}$ in a previously research (data not shown) (BioMérieux, Marcy l'Etoile, France) as $L$. plantarum were assessed. Strains were maintained in Man, Rogosa and Sharpe broth (MRS) (Micromed, Duque de Caxias, RJ) with 20\% (v/v) of glycerol and stored at $-20^{\circ} \mathrm{C}$ until use.

The molecular confirmation of strain's species was performed by multiplex-PCR as described by TORRIANI et al. (2001) for the discrimination of the L. plantarum group strains. Strain DNA was extracted as described by POSPIECH \& NEUMANN (1995), from $2 \mathrm{~mL}$ samples of overnight cultures grown in MRS broth at $37^{\circ} \mathrm{C}$. The recA gene was amplified by multiplex-PCR using the forward primers: planF (5' -CCG TTT ATG CGG AAC ACC
TA-3'), pentF (5' -GGT TTT CAG CGC TGA TAT C-3') and paraF (5' -GTC ACA GGC ATT ACG AAA AC-3'), and a single reverse primer pREV (5' -TCG CCA AAC TTA ATC GGA AC-3'). Three speciesspecific amplification products of different length were obtained: $318 \mathrm{bp}$ for L. plantarum, $218 \mathrm{bp}$ for $L$. pentosus and $107 \mathrm{bp}$ for Lactobacillus paraplantarum.

PCRs were performed on a DNA Engine Systems (PTC 200, Bio Rad, Foster City, USA) with initial denaturation at $94^{\circ} \mathrm{C}$ for $3 \mathrm{~min}$, followed by 30 cycles at $94^{\circ} \mathrm{C}(30 \mathrm{~s}), 1$ cycle at $56^{\circ} \mathrm{C}(10 \mathrm{~s}), 1$ cycle at $72^{\circ} \mathrm{C}(30 \mathrm{~s})$ and a final cycle at $72^{\circ} \mathrm{C}$ for $5 \mathrm{~min}$ (TORRIANI et al., 2001). The amplification products were subjected to gel electrophoresis in agarose gel $(1.5 \%)$ followed by ethidium bromide staining.

\section{Antibiotic Resistant Phenotypes}

Minimal inhibitory concentration (MIC)

MIC was determined using Etest ${ }^{\circledR}$ strips (bioMérieux; Marcy-l'Étoile, France) of ampicillin; streptomycin, chloramphenicol; erythromycin; penicillin $\mathrm{G}$ and tetracycline (0.016 to $\left.256 \mu \mathrm{g} \mathrm{mL}^{-1}\right)$. Resistance to penicillin $\mathrm{G}$ was determined according to the breakpoint proposed for Lactobacillus sp. by the CLSI (2010). Resistance to the other antibiotics was determined according to the breakpoints proposed for Lactobacillus by the EFSA (2008).

\section{Disk diffusion (DD) assay}

The assay was performed with standard disks of ampicillin $(10 \mu \mathrm{g})$; ciprofloxacin $(5 \mu \mathrm{g})$; chloramphenicol $(30 \mu \mathrm{g})$; erythromycin $(15 \mu \mathrm{g})$; gentamicin $(10 \mu \mathrm{g})$; streptomycin $(10 \mu \mathrm{g})$; norfloxacin $(10 \mu \mathrm{g})$; penicillin $\mathrm{G}(10 \mathrm{U})$; tetracycline $(30 \mu \mathrm{g})$; vancomycin $(30 \mu \mathrm{g})$ (Laborclin; Pinhais, Brazil) and trimethoprim $(5 \mu \mathrm{g})$ (Sensifar; São Paulo, Brazil) on MRS (Micromed, Duque de Caxias, RJ) agar plates, incubated at $37^{\circ} \mathrm{C}$ for $24 \mathrm{~h}$.

The inhibition zone diameters obtained for penicillin $G(\leq 19 \mathrm{~mm})$, vancomycin $(\leq 14 \mathrm{~mm})$, tetracycline $(\leq 14 \mathrm{~mm})$, chloramphenicol $(\leq 13 \mathrm{~mm})$ and erythromycin $(\leq 13 \mathrm{~mm})$ were determined according to the breakpoints proposed for Lactobacillus sp. by CHARTERIS et al. (2001). For ampicillin $(\leq 16 \mathrm{~mm})$ and for trimethoprim $(\leq 10 \mathrm{~mm})$, breakpoints recommended for Enterococcus sp. and for Staphylococcus sp., respectively, were used (CLSI 2011). Inhibition zone diameters lower than 9mm were considered as resistance (CLSI 2011).

\section{Statistical analysis}

Results were compared by Chi-square test $(\chi 2)$ with a significance level of $5 \%$. 


\section{RESULTS AND DISCUSSION}

Of 54 L. plantarum strains, 47 strains were distinguished based on recA multiplex-PCR assay. Forty-four (44) strains were confirmed as belonging to the species L. plantarum and 3 strains as L. pentosus. Although they were previously phenotypically identified as L. plantarum, seven (7) strains showed negative PCR results for the primers used and might not belong to the species $L$. plantarum, L. pentosus or L. paraplantarum (Figure 1). The use of primers synthesized from the recA protein gene sequences has been proposed by several authors for the differentiation of genetically similar species of Lactobacillus, such as L. plantarum, L. paraplantarum and L. pentosus (TORRIANI et al., 2001; PENNACCHIA et al., 2006).

Resistance to 4 of 6 antibiotics tested by the gradient technique in scale for the determination of MIC was detected. The highest frequencies of resistance by the MIC method were observed for ampicillin and streptomycin $(58.8 \%$ and $54.2 \%$, respectively). There was also resistance to erythromycin and chloramphenicol $(7.69 \%$ and $1.92 \%$, respectively). All strains were susceptible to tetracycline and penicillin $\mathrm{G}$.

By the DD method, resistance to 9 of 11 antibiotics was reported. All strains (100\%) were resistant to ciprofloxacin, gentamicin, norfloxacin, streptomycin and vancomycin, $92.6 \%$ were resistant to trimethoprim, $59.3 \%$ to ampicillin, $42.6 \%$ to tetracycline and $5.56 \%$ to erythromycin. Conversely, $100 \%$ of the strains were susceptible to chloramphenicol and to penicillin $\mathrm{G}$.

Antibiotic resistance or susceptibility results obtained by $\mathrm{MIC}$ and $\mathrm{DD}$ were similar $(\mathrm{P}>0.05)$ for 4 of 6 antibiotics tested. The highest resistance frequencies to the antibiotics tested in both methods were observed to streptomycin and ampicillin. The methods showed different results $(\mathrm{P}<0.05)$ for streptomycin and tetracycline, for which higher frequency of resistance by DD was reported. For ampicillin, chloramphenicol, erythromycin and penicillin $\mathrm{G}$ no statistical difference $(\mathrm{P}>0.05)$ between the methodologies was reported.

Studies on the comparison of antibiotic resistance by DD and MIC in Lactobacillus sp. are scarce. MAYRHOFER et al. (2008) reported high correlation coefficient ( $\mathrm{r}=0.84$ to 0.98 ) between DD and MIC for susceptibility of $L$. acidophilus to erythromycin, streptomycin and tetracycline, and moderate correlation coefficient $(r=0.63$ to 0.83$)$ to ampicillin, gentamicin and vancomycin. Conversely, in the present study, significant difference $(\mathrm{P}<0.05)$ between DD and MIC for the resistance to streptomycin and tetracycline was reported (Table 1).

THORNSBERRY (1985) recommends that the agreement between DD and microdilution methods should be $\geq 90 \%$. In the present study, the percentages of agreement for the susceptibility to ampicillin, erythromycin, chloramphenicol and penicillin G were $>90 \%$.

Lactobacilli have intrinsic resistance to bacitracin, kanamycin, gentamicin, metronidazole, streptomycin, sulfamethoxazole and vancomycin. The vancomycin-resistant phenotype of some Lactobacillus is perhaps the best characterized intrinsic resistance in LAB (FRAQUEZA, 2015). Several Lactobacillus species are intrinsically resistant to vancomycin because they have D-Ala-Dlactate in the peptidoglycan instead of the dipeptide D-Ala-D-Ala, which prevents vancomycin binding. This resistance is chromosomally encoded and not inducible or transferable (GUEIMONDE et al., 2013).

Resistance to aminoglycosides (neomycin, kanamycin, streptomycin) is also considered intrinsic in Lactobacillus due to the absence of cytochromemediated electron transport, which mediates drug uptake. Lactobacilli are also naturally resistant to quinolones (ciprofloxacin, norfloxacin, nalidixic acid) by an unknown resistance mechanism and are usually resistant to trimethoprim because they have limited biosynthetic capabilities and lack the folic acid synthesis pathway (CHARTERIS et al., 2001).

Although, the high frequency of resistance to vancomycin, ciprofloxacin, norfloxacin, gentamicin, streptomycin and trimethoprim shown by the Lactobacillus strains, it does not represent a major safety concern itself since intrinsic resistance is estimated to present a minimal potential for horizontal spread (FRAQUEZA, 2015). Conversely, Lactobacilli are usually susceptible to antibiotics that inhibit protein synthesis, such as chloramphenicol, erythromycin, lincomycin, clindamycin and tetracyclines (FEDERICI et al., 2014) and to antibiotic that inhibit cell wall synthesis such as penicillins (piperacillin and ampicillin) and b-lactamase inhibitors.

With regards to the resistance of Lactobacillus strains to ampicillin, chloramphenicol, erythromycin, penicillin and tetracycline by $\mathrm{DD}$, $48.1 \%$ of strains were resistant to only one of the antibiotics, $29.6 \%$ to 2 antibiotics and $22.3 \%$ were not resistant to any of those antibiotics. By MIC method, $60.8 \%$ of strains showed resistance to 1 antibiotic, $3.9 \%$ to 2 , whereas $35.3 \%$ showed no resistance to those antibiotics. Thus, none of the Lactobacillus 

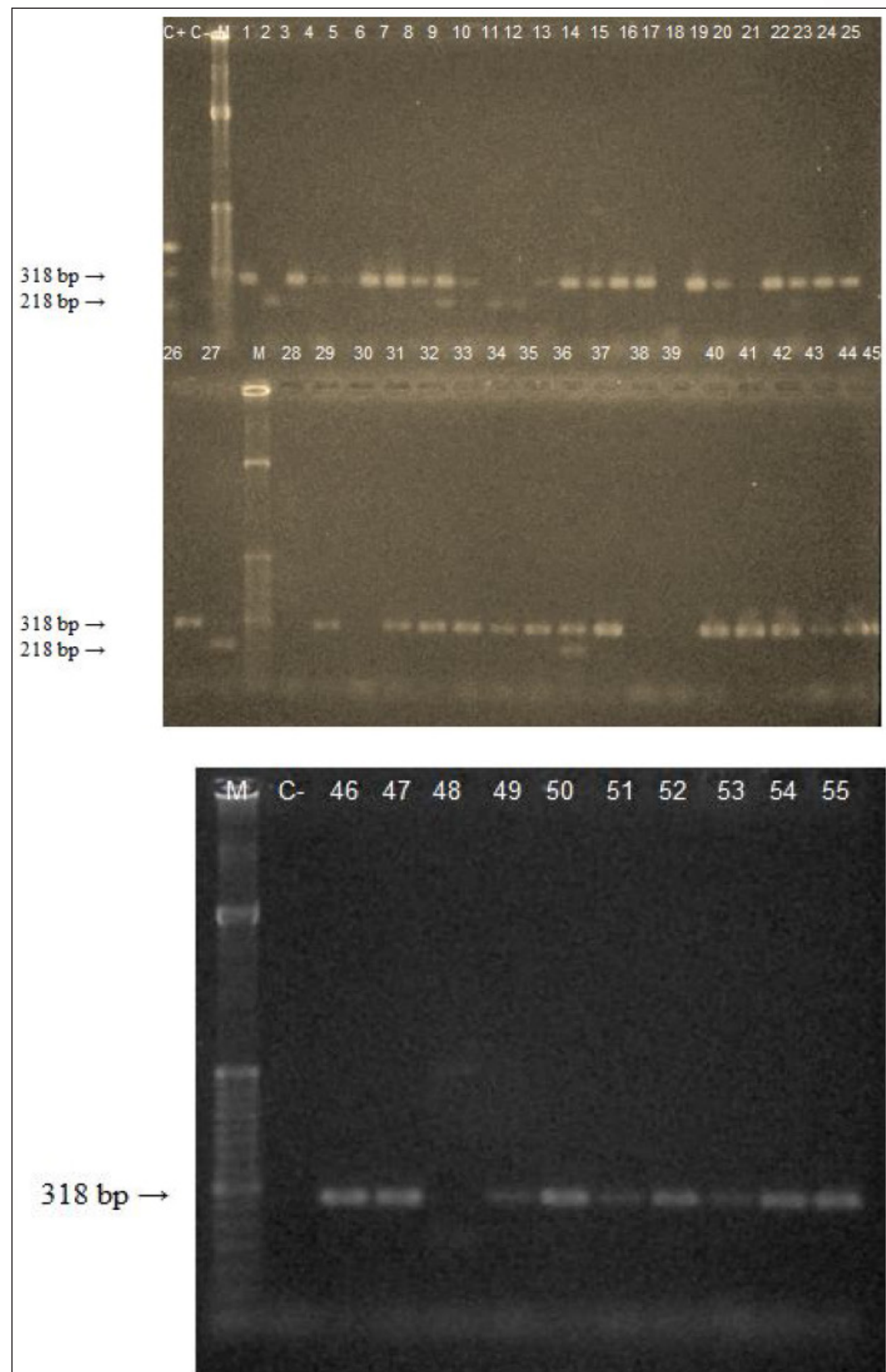

Figure 1 - Agarose gel electrophoresis of DNA fragments generated by multiplex PCR for the L. plantarum group species $($ L. plantarum $=$ strains 1, 3-10, 13-17, 19, 20, 22-27, 29, 31-37, 40-45; L. pentosus $=$ strains 2, 11, 12; strains 18, 21, 28, 30, 38, 39, 48 did not amplified; C+ - E. coli ATCC 25922; C- - negative control; $\mathrm{M}$ - molecular size marker (50bp). 
Table 1 - Comparison of frequency (\%) and agreement (\%) of antibiotic resistance and susceptibility in Lactobacillus sp. isolated from fermented sausages tested by disk diffusion and MIC methods.

\begin{tabular}{|c|c|c|c|c|c|c|}
\hline \multirow{2}{*}{ Antibiotic } & \multicolumn{3}{|c|}{-Resistance------------------------- } & \multicolumn{3}{|c|}{--Susceptibility--- } \\
\hline & $\mathrm{DD} \%$ & $\mathrm{MIC} \%$ & Agr. $\%$ & $\mathrm{DD} \%$ & $\mathrm{MIC} \%$ & Agr $\%$ \\
\hline AMP & 59.3 & 58.8 & 99.15 & 40.7 & 41.2 & 98.78 \\
\hline STR $^{*}$ & 100 & 54.2 & 54.2 & 0 & 45.8 & *** \\
\hline ERY & 5.56 & 7.69 & 72.3 & 94.44 & 92.31 & 97.74 \\
\hline CHL & 0 & 1.92 & *** & 100 & 98.08 & 98.08 \\
\hline TET $^{*}$ & 42.6 & 0 & *** & 57.40 & 100 & 57.40 \\
\hline PEN & 0 & 0 & 100 & 100 & 100 & 100 \\
\hline
\end{tabular}

AMP (Ampicillin), STR (Streptomycin), ERY (Erythromycin), CHL (Chloramphenicol), TET (Tetracycline), PEN (Penicillin G) in concentration of 0.016 to $256 \mu \mathrm{g} \mathrm{mL}{ }^{-1}$. DD $=$ disk diffusion; Agr. $=$ agreement $(\%)$ between methodologies. ${ }^{*} \mathrm{P}<0.05^{* * *}=$ insufficient $^{*}$ numbers of results for test application.

strains tested could be considered multidrug-resistant (resistant to 3 or more classes of antibiotics). This is consistent with the results reported by TURCHI et al. (2013), who did not find multidrug resistance in L. plantarum isolated from Italian food products intended to be used as probiotics. This result might emphasize the classification of QPS status granted to L. plantarum by EFSA (2013).

Considering the MIC doses, $41 \%$ of strains were inhibited at concentration $\leq 2 \mu \mathrm{g} \mathrm{mL}^{-1}$ of ampicillin, $92 \%$ were inhibited at $\leq 1 \mu \mathrm{g} \mathrm{mL} \mathrm{L}^{-1}$ of erythromycin, $98 \%$ were inhibited at $\leq 8 \mu \mathrm{g} \mathrm{mL}^{-1}$ of penicillin G or chloramphenicol and $100 \%$ of strains were inhibited at concentrations $<64 \mu \mathrm{g} \mathrm{mL}^{-1}$ of streptomycin and $\leq 16 \mu \mathrm{g}$ $\mathrm{mL}^{-1}$ of tetracycline (Table 2).

The European Committee on Antimicrobial Susceptibility Testing (EUCAST, 2013) report MIC values for $120 \mathrm{~L}$. plantarum strains; for which $38.33 \%$ of these strains were inhibited at concentration of
$0.25 \mu \mathrm{g} \mathrm{mL}^{-1}$ of ampicillin, $73.33 \%$ at $1 \mu \mathrm{g} \mathrm{mL}^{-1}$ of erythromycin, $65.83 \%$ at $128 \mu \mathrm{g} \mathrm{mL}^{-1}$ of streptomycin and $87.5 \%$ at $16 \mu \mathrm{g} \mathrm{mL}^{-1}$ of tetracycline. In the present study, most of the strains were inhibited at lower concentrations of tetracycline, erythromycin and streptomycin when compared to the EUCAST study.

Multiplicity of methods available for the antibiotic resistance evaluation brings a lack of agreement regarding the resistance-susceptibility breakpoints for most antibiotics in Lactobacillus. AMMOR et al. (2008) report higher breakpoints than those used in the present study for the resistance of $L$. plantarum to ampicillin $\left(4 \mu \mathrm{g} \mathrm{mL} \mathrm{m}^{-1}\right)$ and to erythromycin $\left(4 \mu \mathrm{g} \mathrm{mL} \mathrm{m}^{-1}\right)$. However, in another study, these authors reported that $96.5 \%$ of $L$. plantarum strains were inhibited at concentrations of erythromycin lower than the breakpoint reported $\left(\leq 1 \mu \mathrm{g} \mathrm{mL}^{-1}\right)$. They also reported that $96.5 \%$ of $L$. plantarum strains were inhibited at concentrations

Table 2 - Distribution of MICs (Minimum Inhibitory Concentrations) for Lactobacillus sp. strains isolated from fermented sausages.

\begin{tabular}{|c|c|c|c|c|c|c|c|c|c|c|c|c|c|c|c|c|c|c|}
\hline \multirow{2}{*}{ Antib. } & \multicolumn{18}{|c|}{$-\mathrm{MIC}\left(\mu \mathrm{g} \mathrm{mL}^{-1}\right) /$ Isolates $(\%)-$} \\
\hline & 0.094 & 0.125 & 0.19 & 0.25 & 0.38 & 0.50 & 0.75 & 1 & 1.5 & 2 & 3 & 4 & 6 & 8 & 12 & 16 & 24 & 32 \\
\hline AMP & 4 & & & & & & & & 2 & 35 & 51 & 8 & & & & & & \\
\hline CHL & & & & & & & & & & 17 & 52 & 21 & 8 & & 2 & & & \\
\hline ERY & & 4 & 2 & 11 & 35 & 28 & 8 & 4 & & 4 & & & & 2 & 2 & & & \\
\hline PEN & & 2 & 9 & 9 & 36 & 26 & 2 & 7 & 7 & & & & & & & & & 2 \\
\hline STR & & & & & & & & & & & & 8 & & & 4 & 33 & 38 & 17 \\
\hline TET & & & & & & & & & 4 & 8 & 29 & 15 & 19 & 13 & 10 & 2 & & \\
\hline
\end{tabular}

Antibiotic/ Resistance breakpoint $\left(\mu \mathrm{g} \mathrm{mL} \mathrm{mL}^{-1}\right)$ : AMP (Ampicillin/ 2), CHL (Chloramphenicol/ >8), ERY (Erythromycin/ 1), PEN (Penicillin G/ >8), STR (Streptomycin/ 64), TET (Tetracycline/ 32). 
$\leq 8 \mu \mathrm{g} \mathrm{mL}-1$ of chloramphenicol, $\leq 32 \mu \mathrm{g} \mathrm{mL} \mathrm{m}^{-1}$ of tetracycline and $\leq 64 \mu \mathrm{g} \mathrm{mL}^{-1}$ of streptomycin.

Results obtained for resistance to streptomycin and tetracycline showed higher accuracy of the DD method than the MIC in detecting resistant Lactobacillus strains. In fact, $45.8 \%$ of strains identified as resistant to streptomycin by DD were not identified as resistant by MIC, whereas $42.6 \%$ of strains identified as resistant to tetracycline by DD were identified as susceptible to this antibiotic by MIC. This confirmed the necessity of more specific inhibition zone range values for interpretation of data from strains belonging to the species L. plantarum, since neither CLSI nor EFSA established breakpoints for the assessment of antibiotic resistance by DD in this species.

In this study, a breakpoint data set was generated for 54 indigenous Lactobacillus strains to 06 antimicrobials used in food animals. Distribution of MIC values enables the proposal of consistent breakpoints data for $L$. plantarum since there is no consensus on the breakpoints for this genus and species by CLSI and EFSA.

\section{CONCLUSION}

Of 54 indigenous Lactobacillus strains isolated from fermented sausages, 44 were genotypically confirmed as belonging to the $L$. plantarum species and 3 as L. pentosus. None of the strains showed multidrug resistance (non-intrinsic resistance). DD showed higher accuracy than MIC in detecting streptomycin and tetracycline resistant strains. Future research should focus on the genetic mechanisms underlying the phenotypic resistance by analyzing antibiotic resistance genes in the potential probiotic Lactobacillus strains in order to estimate the possibility of transferring genes to other bacteria present in the gastrointestinal tract of consumers.

\section{ACKNOWLEDGMENTS}

The authors thank Coordenação de Aperfeiçoamento de Pessoal de Nível Superior (CAPES), Brazil, by granting scholarship to Hanna L. Wolupeck and financial aid to the project.

\section{REFERENCES}

AMMOR, M.S. et al. Molecular characterization of intrinsic and acquired antibiotic resistance in lactic acid bacteria and bifidobacteria. Journal of Molecular Microbiology and Biotechnology, v.14, p.6-15, 2008. Available from: $<$ https://www. karger.com/Article/Pdf/106077>. Accessed: Feb. 10, 2015. doi: $10.1159 / 000106077$.
CHARTERIS, W.P. et al. Gradient diffusion antibiotic susceptibility testing of potentially probiotic lactobacilli. Journal of Food Protection, v.64, n.12, p.2007-2014, 2001. Available from: <http://www.ingentaconnect.com/content/iafp/ jfp/2001/00000064/00000012/art00020>. Accessed: Jan. 30, 2015.

CLSI. Methods for antimicrobial dilution and disk susceptibility testing of infrequently isolated or fastidious bacteria. Approved guideline. 2; ed. Wayne, PA: Clinical and Laboratory Standards Institute, 2010. CLSI document M45 - A2.

CLSI. Performance standards for antimicrobial susceptibility testing, Twenty-first Informational Supplement. Wayne, PA: Clinical and Laboratory Standards Institute, 2011. CLSI document M100 - S21.

DALLA SANTA, O.R. et al. Microbiota of sausages obtained by spontaneous fermentation produced in the South of Brazil. Ciência e Tecnologia de Alimentos, v.32, n.4, p.653-660, 2012. Available from: $\quad<$ http://www.scielo.br/pdf/cta/v32n4/aop cta_3850.pdf $>$. Accessed: Feb. 10, 2015. doi: 10.1590/S010120612012005000117.

EFSA. Technical guidance - Update of antibiotic resistance criteria. EFSA Journal, v.732, p.2-15, 2008. Available from: $<$ http://www.efsa.europa.eu/sites/default/files/scientific output/ files/main_documents/732.pdf $>$. Accessed: Apr. 10, 2015.

EFSA. Scientific Opinion on the maintenance of the list of QPS biological agents intentionally added to food and feed. EFSA Journal, v.11, n.11, p.3449, 2013. Available from: <http://www. efsa.europa.eu/sites/default/files/scientific_output/files/main documents/3449.pdf>. Accessed: Apr. 10, 2015.

EUCAST. European Society of Clinical Microbiology and Infectious Diseases. Antimicrobial wild type distributions of microorganisms. 2013. Available from: <http://mic.eucast. org/Eucast2/SearchController/search.jsp?action=performSear ch\&BeginIndex $=0 \&$ Micdif $=$ mic $\&$ NumberIndex $=50 \&$ Antib $=$ 1\&Specium=577>. Accessed: Oct. 19, 2015.

FEDERICI, S. et al. Identification and functional traits of lactic acid bacteria isolated from Ciauscolo salami produced in Central Italy. Meat Science, v.98, p.575-584, 2014. Available from: $<$ http:// www.sciencedirect.com/science/article/pii/S0309174014001508>. Accessed: Feb. 10, 2015. doi: 10.1016/j.meatsci.2014.05.019.

FRAQUEZA, M.J. Antibiotic resistance of lactic acid bacteria isolated from dry-fermented sausages. International Journal of Food Microbiology, v.212, p.76-88, 2015. Available from: $<$ http:// www.sciencedirect.com/science/article/pii/S016816051500238X>. Accessed: Feb. 10, 2015. doi: 10.1016/j.ijfoodmicro.2015.04.035.

GUEIMONDE, M. et al. Antibiotic resistance in probiotic bacteria. Frontiers in Microbiology, v.4, n.202, p.6, 2013. Available from: $<$ http://www.ncbi.nlm.nih.gov/pmc/articles/PMC3714544/pdf/ fmicb-04-00202.pdf>. Accessed: Feb. 10, 2015. doi: 10.3389/ fmicb.2013.00202.

KLINGBERG, T.D. et al. Identification of potential probiotic starter cultures for Scandinavian-type fermented sausages. International Journal of Food Microbiology, v.105, n.3, p.419-431, 2005. Available from: $<$ http://www.sciencedirect.com/science/article/pii/ S0168160505003442>. Accessed: Feb. 10, 2015. doi: 10.1016/j. ijfoodmicro.2005.03.020. 
MAYRHOFER, S. et al. Comparison of broth microdilution, Etest, and agar disk diffusion methods for antimicrobial susceptibility testing of Lactobacillus acidophilus group members. Applied and Environmental Microbiology, v.74, n.12, p.3745-3748, 2008 Available from: <http://aem.asm.org/content/74/12/3745.full. pdf + html $>$. Accessed: Mar. 23, 2015. doi: 10.1128/AEM.02849-07.

PENNACCHIA C. et al. Potential probiotic Lactobacillus strains from fermented sausages: Further investigations on their probiotic properties. Meat Science, v.73, p.90-101, 2006. Available from: $<$ http://www.sciencedirect.com/science/article/pii/ S0309174005004006>. Accessed: Feb. 10, 2015. doi: 10.1016/j. meatsci.2005.10.019.

POSPIECH, A.; NEUMANN, B. A versatile quick-prep of genomic DNA from gram-positive bacteria. Trends in Genetic, v.11, n.6, p.217-218, 1995. Available from: <http://www.sciencedirect.com/ science/article/pii/S0168952500890526>. Accessed: Feb. 10, 2015. doi: 10.1016/S0168-9525(00)89052-6.

THORNSBERRY, C. Automated procedures for antimicrobial susceptibility tests. In: LENETTE, E.H. et al. (Eds.). Manual of clinical microbiology. Washington: American Society for Microbiology, 1985. p.1015-1018.

TORRIANI, S. et al. Differentiation of Lactobacillus plantarum, L. pentosus, and L. paraplantarum by recA gene sequence analysis and multiple PCR assay with recA gene-derived primers. Applied Environmental Microbiology, v.67, p.3450-3454, 2001. Available from: <http://aem.asm.org/content/67/8/3450>. Accessed: Feb. 10, 2015. doi: 10.1128/AEM.67.8.3450-3454.2001.

TURCHI, B. et al. Preliminary evaluation of probiotic potential of Lactobacillus plantarum strains isolated from Italian food products. World Journal of Microbiology and Biotechnology, v.29, n.10, p.1913-1922, 2013. Available from: <http://link.springer.com/ article/10.1007/s11274-013-1356-7\#page-1>. Accessed: Feb. 10, 2015. doi: 10.1007/s11274-013-1356-7.

WHO (WORLD HEALTH ORGANIZATION). Antimicrobial resistance: global report on surveillance. Geneva, Switzerland, 2014. 232p. Available from: <http://apps.who.int/iris/ bitstream/10665/112642/1/9789241564748_eng.pdf.>. Accessed: Aug. 30, 2014. 